УДК 697.94.(075)

Д. І. Гарасим, В. Й. Лабай

Національний університет «Львівська політехніка», вул. Ст. Бандери, 12, Львів, 79013, Україна

\title{
ЗАЛЕЖНІСТЬ ЕКСЕРГЕТИЧНОГО ККД СИСТЕМИ КОНДИЦІЮВАННЯ ПОВІТРЯ ОПЕРАЦІЙНИХ ЧИСТИХ КІМНАТ ВІД ТЕМПЕРАТУРИ І ВОЛОГОВМІСТУ НАВКОЛИШНЬОГО СЕРЕДОВИЩА
}

У статті використана авторська інноващійна математична дослідницька модель впровадженої иентральної прямотечійної системи кондиціювання повітря операційних чистих кімнат. Мета моделі - комп ютерне оцінювання ексергетичної ефективності діючої системи кондиціювання залежно від різних факторів, шуо впливають на ї роботу, зокрема температури і вологовмісту навколишнього середовища. Завдяки иій моделі встановлено вплив температури і вологовмісту навколишнього середовища на ексергетичний ККД діючої системи кондиціювання.

Ключові слова: Ексергетичний баланс; Системи кондиціювання повітря; Чисті приміщення; Ексергетична ефективність; Температура і вологовміст навколишнього середовища

This work is licensed under the Creative Commons Attribution International License (CC BY).

http://creativecommons.org/licenses/by/4.0

\section{I. ВСТУП}

В останні десятиріччя за кордоном 3 метою заощадження енергетичних ресурсів ведуться фундаментальні дослідження діяльності ряду галузей, виробництв і технологій із позицій ексергетичної методології $[6-10,12,13,15,16]$. Ця методологія була обгрунтована у роботах Р.К. Клаузіуса, Дж.В. Гіббса, Ж. Гюі, А. Стодоли, Я. Шаргута та Р. Петели. Величина, що визначає придатність до дії (працездатність) ресурсів речовини та енергії, була названа ексергією, а функції, що визначають іiї значення, - ексергетичними. Термін «ексергія», що визначає придатність до дії (працездатність) ресурсів речовини та енергії, був введений у 1956 році.

У сучасних технологіях, пов'язаних 3 перетворенням енергії, а саме у системах кондиціювання повітря (СКП), важливе місце займають обладнання і процеси, об'єктивна оцінка ступеня енергетичної досконалості яких може бути встановлена тільки на основі аналізу їх ексергоефективності.

Для всебічного вивчення за допомогою ексергетичного аналізу енерготехнологічних систем (ЕTC) таких, як системи кондиціювання повітря, важливо враховувати не тільки процеси всередині системи, але й можливі види взаємодії потоків енергії, пов'язані 3 даною системою, поза їі межами. Тільки так можливо дати повну інженерну оцінку придатності і корисності всіх потоків енергії за даних параметрів та на ії основі зробити ексергетичний аналіз технічної системи.

Усі процеси в СКП проходять в умовах, які визначаються навколишнім середовищем. Ці умови чинять вирішальний вплив на спосіб реалізації процесів кондиціювання повітря. У процесах кондиціювання, як правило, навколишнє середовище використовується як поглинач теплоти, оскільки цей поглинач є при- роднім. Тому температура навколишнього середовища $\epsilon$ суттєвим параметром під час технічного здійснення процесів кондиціювання. Окрім цього, навколишнє зовнішнє повітря є носієм чистого повітря для людей.

Параметри навколишнього середовища звичайно для процесів кондиціювання повітря прийнято вважати сталими протягом певного часу, але загалом вони $є$ змінними.

Разом 3 тим параметри навколишнього середовища (зовнішнього повітря) для обладнання СКП визначають не тільки параметри їх роботи, але й параметри внутрішнього повітря всередині приміщення, які своєю чергою впливають на параметри роботи обладнання СКП.

Ексергетичний баланс для даної ЕТС, тобто впровадженої авторами системи кондиціювання повітря операційних чистих кімнат, має такий вигляд:

$$
E_{\text {вх }}=E_{\text {вих }}+\sum_{i=1}^{n} D_{i},
$$

де $E_{\mathrm{Bx}}-$ ексергія приводу СКП, яка витрачається на підтримання процесу, Вт; $E_{\text {вих }}-$ приріст ексергії повітря у кондиціонованих приміщеннях, Вт; $\sum_{i=1}^{n} D_{i}-$ сума ексергетичних втрат ЕТС, Вт.

Ексергетичний баланс даної ЕТС складали на основі їі принципової схеми (рисунок 1).

Вочевидь, досконалість ЕТС та ії елементів тим вища, чим вищий ексергетичний ККД, який визначали 3 ексергетичного балансу, а саме [6-10, 12, 13, 1520]:

$$
\eta_{\mathrm{e}}=\frac{E_{\mathrm{Bux}}}{E_{\mathrm{Bx}}} .
$$


Розрахунок ексергетичного ККД ЕТС створює умови для вирішення питання економії паливноенергетичних ресурсів [7, 8, 11-13, 16, 18-20].

Отже, ексергетичний ККД ЕТС обраховували за формулою (2), в якій чисельник є корисним ексергетичним ефектом, а знаменник - затратами ексергії, а отже ексергетичний ККД визначали за формулою:

$$
\eta_{\mathrm{e}}=\frac{E_{\text {вих }}}{E_{\text {вих }}+\sum_{i=1}^{n} D_{i}}=\frac{E_{\text {еф }}}{E_{\text {затр }}} .
$$

Ефективність роботи будь-якої системи кондиціювання повітря, як було відзначено, залежить від параметрів навколишнього середовища, а саме температури і вологовмісту зовнішнього повітря.

Тому метою даної роботи було дослідити вплив температури і вологовмісту зовнішнього повітря на ексергетичний ККД $\eta_{\text {e }}$ впровадженої центральної прямотечійної СКП операційних чистих кімнат.

\section{II. ОПИСАННЯ ОБ'ЄКТУ АНАЛІЗУ ТА ІННОВА- ЦЙНОї ДОСЛІДНИЦЬКОЇ МОДЕЛІ}

Метою кондиціювання повітря є підтримання у деякому обмеженому просторі (у даному випадку у чистих операційних кімнатах) певних параметрів повітря. Звичайно регулюванню підлягає температуpa $t_{\mathrm{B}}$ і відносна вологість $\varphi_{\mathrm{B}}$ повітря, а у чистих операційних кімнатах це ще й концентрація частинок $x_{\text {в }}$ у повітрі [1-5]. Як відомо вибір внутрішньої темпера-

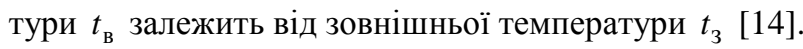

Розглянемо впроваджену авторами центральну прямотечійну СКП для операційних чистих кімнат, схематично зображену на рисунку 1 . Робота такої системи залежить від домінуючих у зовнішньому середовищі умов, тобто від температури і вологовмісту зовнішнього повітря. Отже, у теплий період року (ТПР) зовнішнє повітря через клапан 11 забирається центральним кондиціонером, очищається у фільтрі 10, далі проходить через повітронагрівник 9, охолоджується та осушується за політропою у повітроохолоднику 8 , сепарується у краплевловнику 7 , а відтак вентиляторним агрегатом 6 подається через фільтр кондиціонера 5 і фільтри 3 на вході у чисті операційні кімнати. Видаляється відпрацьоване повітря 3 операційних чистих приміщень 3 верхньої і нижньої зон витяжною установкою через іiі клапан 17 витяжним вентилятором 18.

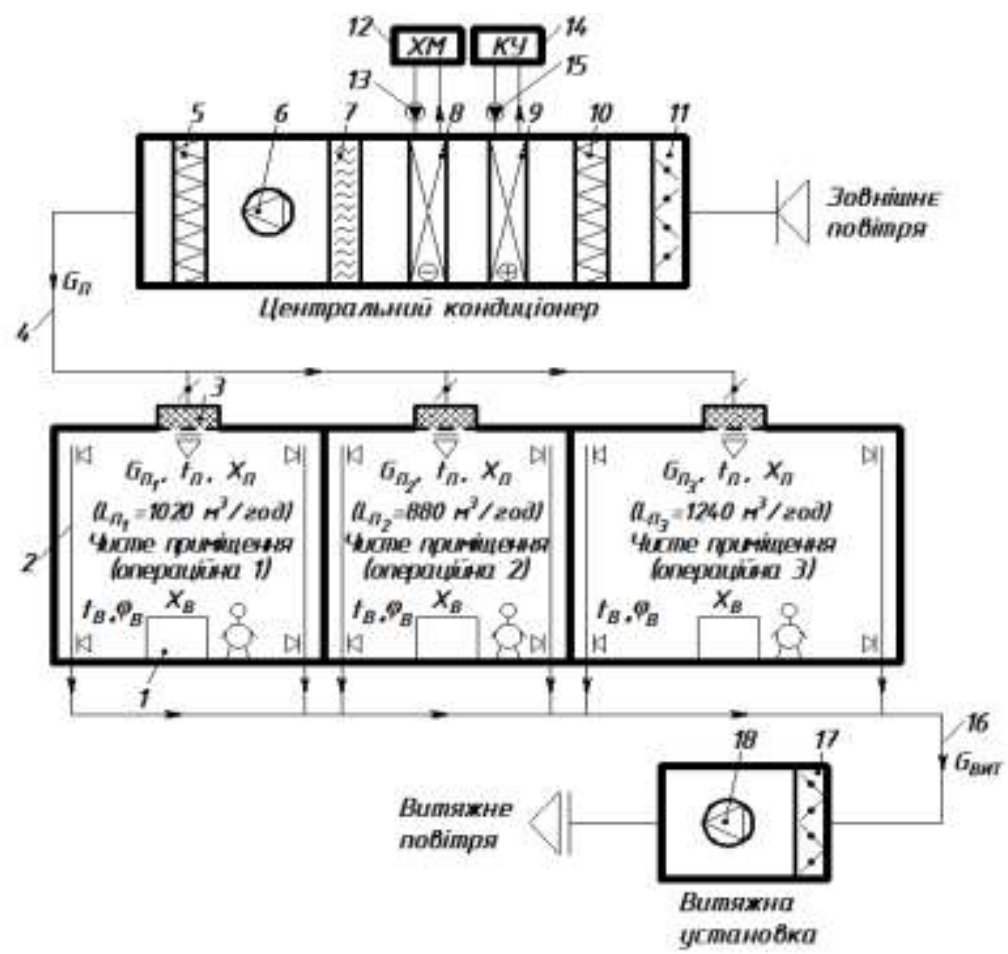

Рисунок 1 - Принципова схема впровадженої ичентральної прямотечійної СКП для операційних чистих кімнат: 1 - технологічне обладнання; 2 - витяжні канали у приміщеннях;

3 - фільтри припливного повітря у приміщення; 4 - припливний повітропровід;

5 - фільтр припливного повітря у кондиціонері; 6 - вентиляторний агрегат кондиціонера;

7 - краплевловник кондиціонера; 8 - повітроохолодник кондиціонера;

9 - повітронагрівник кондиціонера; 10 - фільтр зовнішнього повітря у кондиціонері;

11 - клапан зовнішнього повітря у кондиціонері; 12 - холодильна машина ХМ;

13 - насос холодної води ХМ; 14 - котельна установка КУ; 15 - насос гарячої води;

16 - витяжний повітропровід; 17 - клапан витяжного повітря;

18 - вентиляторний агрегат витяжної установки 
Наведемо роботу даної СКП у ТПР, коли температура $t_{\mathrm{B}}<t_{3}$. На рисунку 2 приведена у системі координат $I, d$ послідовність зміни параметрів повітря, яке проходить через різне обладнання впровадженої центральної прямотечійної системи кондиціювання повітря для операційних чистих кімнат у ТПР за різних параметрів зовнішнього повітря.

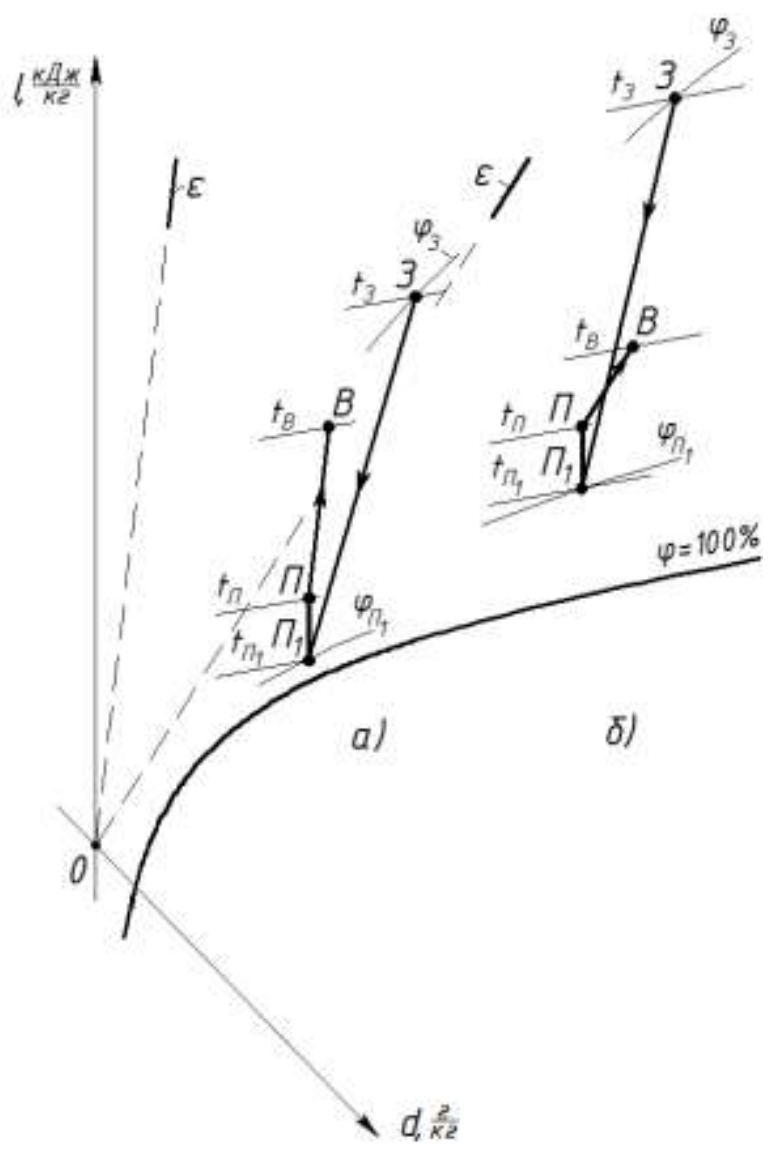

Рисунок 2 - Зображення процесів зміни стану вологого повітря у діючій прямотечійній СКП у ТПР на I-d - діаграмі

а) для умов проведення досліджень $-t_{3}=30 ; 32^{\circ} \mathrm{C}$;

$$
t_{\mathrm{B}}=25 ; 26^{\circ} \mathrm{C} ; \Delta t_{\Pi}=9 ; 7^{\circ} \mathrm{C} ;
$$

б) для умов проведення досліджень $-t_{3}=35 ; 38$;

$40^{\circ} \mathrm{C} ; t_{\mathrm{B}}=27 ; 28 ; 29^{\circ} \mathrm{C} ; \Delta t_{\Pi}=6 ; 5 ; 4^{\circ} \mathrm{C}:$

$3 \Pi_{1}$ - процес політропного оброблення (охолодження та осушування) повітря $G_{3}=G_{\Pi}$ у повітроохолоднику;

$\boldsymbol{\Pi}_{\boldsymbol{I}} \boldsymbol{\Pi}$ - прочес підігрівання повітря $G_{\Pi}$ на $1^{\circ} \mathrm{C}$ у вентиляторі та припливному повітропроводi;

ПВ - прочес асиміляції тепло- $i$ вологонадлишків у чистих приміщеннях припливним повітрям $G_{\text {п }} 3$ кондиціонера

У дослідженнях прийнято масову продуктивність СКП, пораховану за необхідною кратністю повітрообміну, $G=4300$ кг/год, параметри зовнішнього повітря змінювались у межах: температура $t_{3}=30-40^{\circ} \mathrm{C}$; відносна вологість $\varphi_{3}=44-36 \%$ (відповідно, питома енталь- пія вологовміст $d_{3}=11,7-16,8$ г/кг; $I_{3}=$ $=60,1-83,4$ кДж/кг), барометричний тиск $p_{3}=$ = 1010 гПа; параметри внутрішнього повітря відповідно $\quad-\quad t_{\mathrm{B}}=25-29^{\circ} \mathrm{C} ; \quad \varphi_{\mathrm{B}}=54-64 \% \quad$ (відповідно, $d_{\mathrm{B}}=10,8-16,3$ г/кг; $I_{\mathrm{B}}=52,6-70,8$ кДж/кг); різниця температур між внутрішнім і припливним повітрям залежно від теплонадлишків у чистому приміщенні, а також температури зовнішнього повітря $\Delta t_{\Pi}=t_{\mathrm{B}}-t_{\Pi}=9,0-4,0^{\circ} \mathrm{C}$; кутовий коефіцієнт процесу асиміляції тепло- і вологонадлишків у чистих приміщеннях припливним повітрям 3 кондиціонера $\varepsilon=$ $=27058-9711$ кДж/кг; початкова температура холодоносія (40\% розчину пропіленгліколю) для повітроохолодника: $t_{\mathrm{B}_{\text {п }}}=9,5-15,5^{\circ} \mathrm{C}$.

Послідовність змін, які відбуваються з вологим повітрям, що проходить через різне обладнання впровадженої системи кондиціювання повітря, наведені на рисунку 2 . Побудова на $I-d$ - діаграмі запропонована нами та виконана згідно з [11]. Параметри повітря у характерних точках процесу (рисунок 2) встановлювались за значеннями відповідних параметрів для зовнішнього повітря та підраховувались за відомими аналітичними залежностями для вологого повітря.

Авторами була створена інноваційна дослідницька математична модель впровадженої системи кондиціювання повітря для комп'ютерного оцінювання іiї ексергетичної ефективності залежно від різних параметрів зовнішнього і внутрішнього повітря та різниці температур між внутрішнім і припливним повітрям. Завдяки цій моделі отримано результати досліджень, які зведені у таблицю 1.

Ексергетичний ККД, який характеризує ефективність роботи впровадженої центральної прямотечійної системи кондиціювання операційних чистих кімнат у ТПР, визначали за формулою (3), у якій $E_{\text {вих }}=E_{\Pi}-E_{\mathrm{B}}-$ зменшення ексергії кондиціонованого повітря у чистих кімнатах кардіологічних операційних (корисно використана ексергія), Вт; $E_{\Pi}$ i $E_{\text {В }}-$ відповідно, ексергія припливного і внутрішнього повітря у чистих кімнатах, Вт; $D_{П о}=E_{\Pi_{1}}-E_{3}-$ втрата ексергії повітря у повітроохолоднику кондиціонера, Вт; $E_{\Pi_{1}}$ і $E_{3}-$ відповідно, ексергія оброблюваного повітря на виході та вході (зовнішнього повітря) у повітроохолодник кондиціонера, Вт; $D_{\Pi_{1} \Pi}=E_{\Pi_{1}}-E_{\Pi}-$ втрата ексергії повітря під час його транспортування у припливних повітропроводах і вентиляторі СКП, Вт; $E_{\Pi_{1}}$ і $E_{\Pi}-$ відповідно, ексергія повітря на вході у припливний вентилятор кондиціонера та виході з припливних повітропроводів у чисті кімнати, Вт; $D_{\text {вит }}=E_{\mathrm{B}}-E_{3}-$ втрати ексергії з витяжним кондиціонованим повітрям 3 чистих кімнат, Вт; $D_{\text {пр.вент }}-$ втрата ексергії з припливним вентилятором кондиціонера, Вт; $D_{\text {вит.вент }}$ - втрата ексергії 3 вентилятором витяжної установки, Вт; $D_{\mathrm{XM}}$ - втрата ексергії з холодильною машиною центрального кондиціонера, Вт. 
Таблиця 1 - Параметри точок, які характеризують стан вологого повітря під час роботи впровадженої центральної прямотечійної СКП з рекуперативним повітроохолодником повітропродуктивністю 4300 кг/год

\begin{tabular}{|l|l|l|l|l|l|}
\hline $\begin{array}{c}\text { Точки на } \\
I-d-\text { діаграмі }\end{array}$ & \multicolumn{1}{|c|}{$\begin{array}{c}\text { Температура } \\
t,{ }^{\circ} \mathrm{C}\end{array}$} & $\begin{array}{c}\text { Питома } \\
\text { ентальпія } \\
I, \text { кдж/кг }\end{array}$ & $\begin{array}{c}\text { Вологовміст } \\
d, \text { г/кг }\end{array}$ & $\begin{array}{c}\text { Відносна } \\
\text { вологість } \\
\varphi, \%\end{array}$ & $\begin{array}{c}\text { Питома } \\
\text { ексергія } \\
e, \text { кдж/кг }\end{array}$ \\
\hline $\mathbf{3 ( O )}$ & $30-40$ & $50,3-83,4$ & $7,9-16,8$ & $30-44$ & $0,0-0,0$ \\
\hline $\mathbf{\Pi}_{\mathbf{1}}$ & $15,0-24,0$ & $32,3-64,7$ & $6,7-15,8$ & $63-84$ & $0,4038-0,4421$ \\
\hline $\mathbf{\Pi}$ & $16,0-25,0$ & $33,0-65,4$ & $6,7-15,8$ & $59-79$ & $0,3527-0,3882$ \\
\hline $\mathbf{B}$ & $25-29$ & $43,0-70,8$ & $7,0-16,3$ & $35-64$ & $0,0497-0,2059$ \\
\hline
\end{tabular}

Отже, загальні втрати ексергії у діючій СКП визначали так:

$$
\begin{aligned}
& \sum_{i=1}^{n} D_{i}=D_{\text {ПО }}+D_{\Pi_{1} \Pi}+D_{\text {вит }}+ \\
& +D_{\text {пр.вент }}+D_{\text {вит.вент }}+D_{\text {ХМ }}, \text { Вт. }
\end{aligned}
$$

Як конкретно визначали величини, що входять у формулу (3) подано у [19, 20].

\section{ІІІ. РЕЗУЛЬТАТИ ДОСЛІДНИЦЬКОЇ РОБОТИ}

На основі досліджень, проведених нами на інноваційній математичній моделі для вказаної СКП, отримано залежність ексергетичного ККД $\eta_{\mathrm{e}}$ від параметрів зовнішнього $\left(t_{3}, d_{3}\right)$ повітря за різних внутpiшнix $\left(t_{\mathrm{B}}, \varphi_{\mathrm{B}}\right)$ параметрів та різниці температур $\Delta t_{\text {п }}$ між внутрішнім і припливним повітрям, які подані на рисунку 3.

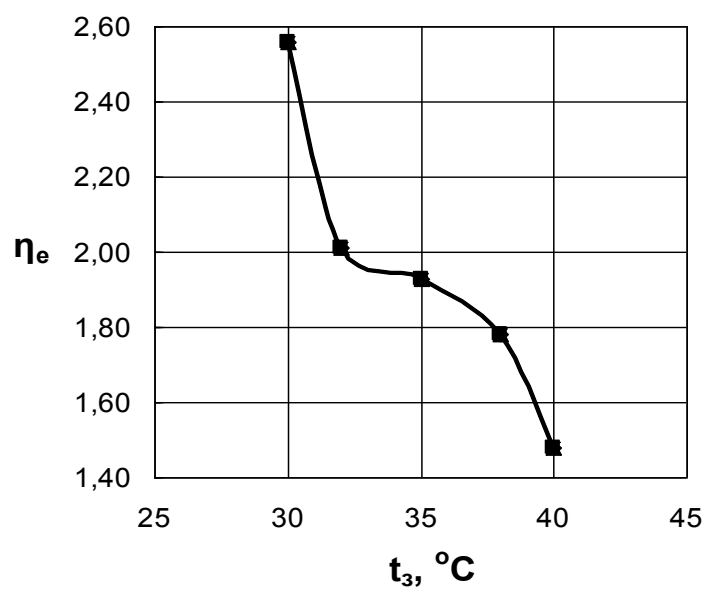

Рисунок 3 - Залежність ексергетичного ККД $\eta_{\mathrm{e}}$ впровадженої ичентральної прямотечійної

СКП операційних чистих кімнат

з рекуперативним повітроохолодником повітропродуктивністю 4300 кг/год від температури $t_{3} i$ вологовмісту зовнішнього повітря:

1 ряд - $d_{\mathrm{c}}=7,9-13,9$ г/кг; 2 ряд $\mathbf{\square}-8,7-14,9$;

3 ряд А - 9,6-15,4; 4 ряд к-10,6-15,8; 5 ряд $\mathrm{x}-11,7-16,8$

(залежність від вологовмісту для всіх рядів однакова)
Аналізуючи отримані дані досліджень на рисунку 3 і у таблиці 1, можна дійти таких висновків. За певної температури навколишнього середовища $t_{3}$ (зовнішнього повітря) зростання вологовмісту зовнішнього повітря $d_{3}$ не призводить до зміни значення ексергетичного ККД $\eta_{\mathrm{e}}$ впровадженої СКП. Тобто, значення ексергетичного ККД $\eta_{\mathrm{e}}$ впровадженої СКП залежить тільки від температури зовнішнього повітря $t_{3}$ та різниці температур між внутрішнім і припливним повітрям $\Delta t_{\text {п }}=t_{\text {в }}-t_{\text {п }}$.

Загальне зростання температури зовнішнього повітря $t_{3}$ від 30 до $40^{\circ} \mathrm{C}$, тобто в 1,33 рази, призводить до значного зменшення значення ексергетичного ККД $\eta_{\mathrm{e}}$ від 2,56 до 1,48 , тобто в 1,73 рази або на $73 \%$. На нашу думку це пов'язано не стільки зі зростанням температури зовнішнього повітря $t_{3}$, як з одночасним зменшенням різниці температур між внутрішнім $\mathrm{i}$ припливним повітрям $\Delta t_{\text {п }}=t_{\text {в }}-t_{\text {п }}$ від 9,0 до $4,0^{\circ} \mathrm{C}$, тобто в 2,25 рази або на $125 \%$. Тому впроваджену систему кондиціювання повітря бажано використовувати за нижчих температур зовнішнього повітря, а саме, наприклад $t_{3}=30^{\circ} \mathrm{C}$, та 3 якомога найвищою різницею температур між внутрішнім і припливним повітрям $\Delta t_{\text {п }}=t_{\text {в }}-t_{\text {п }}$, наприклад, $\Delta t_{\text {п }}=9,0^{\circ} \mathrm{C}$, що дасть можливість отримати найвищий ексергетичний ККД $\eta_{\mathrm{e}}$ $=2,56$, а значить отримати економічно найвигідніший варіант використання впровадженої системи кондиціювання повітря.

Варто звернути увагу (рисунок 3), що за температури зовнішнього повітря $t_{3}$ від 30 до $32^{\circ} \mathrm{C}$ маємо один закон зміни ексергетичного ККД $\eta_{\mathrm{e}}$, а за температури зовнішнього повітря $t_{3}$ від 32 до $40^{\circ} \mathrm{C}$ - інший. Це можливо пояснити тим, що температура внутрішнього повітря у чистому приміщенні приймається порізному до температури зовнішнього повітря $t_{3}=30^{\circ} \mathrm{C}$ і після неї. Тому ці зміни розглянемо окреMo.

Отже, зростання температури зовнішнього повітря $t_{3}$ від 30 до $32^{\circ} \mathrm{C}$, тобто в 1,07 рази, призводить до 
значного зменшення значення ексергетичного ККД $\eta_{\mathrm{e}}$ від 2,56 до 2,01 , тобто в 1,27 рази або на $27 \%$. Разом 3 тим середня швидкість зміни ексергетичного ККД $\eta_{\mathrm{e}}$ на цій початковій ділянці $\Delta \eta_{\mathrm{e}} / \Delta t_{3}$ становить $0,2751 /{ }^{\circ} \mathrm{C}$.

Відповідно зростання температури зовнішнього повітря $t_{3}$ від 32 до $40^{\circ} \mathrm{C}$, тобто в 1,25 рази, призводить до зменшення значення ексергетичного ККД $\eta_{\mathrm{e}}$ від 2,01 до 1,48 , тобто 1,36 рази або на $36 \%$. В той самий час середня швидкість зміни ексергетичного ККД $\eta_{\mathrm{e}}$ на цій ділянці $\Delta \eta_{\mathrm{e}} / \Delta t_{3}$ становить $0,0661 /{ }^{\circ} \mathrm{C}$, що в 4,17 рази менше, тобто на $317 \%$, ніж на початковій ділянці.

Залежності, наведені на рисунку 3, отримані нами у вигляді аналітичних формул для температур зовнішнього повітря $t_{3}=30-32^{\circ} \mathrm{C}$ :

$$
\eta_{\mathrm{e}}=10,81-0,275 \cdot t_{3}
$$

а для $t_{3}=32-40^{\circ} \mathrm{C}$ :

$$
\eta_{\mathrm{e}}=0,6509 \cdot t_{3}-0,0099 \cdot t_{3}^{2}-8,6769 .
$$

Максимальна похибка розрахунків за формулою (5) становить $0 \%$ і за формулою (6) - 2,7\%.

Значить ексергетичний аналіз впровадженої центральної прямотечійної системи кондиціювання повітря операційних чистих кімнат виконаний на створеній авторами інноваційній математичній дослідницькій моделі дав можливість грунтовно оцінити залежність ексергетичного ККД $\eta_{\mathrm{e}}$ цієї системи від параметрів зовнішнього $\left(t_{3}, d_{3}\right)$ повітря за різних внутрішніх $\left(t_{\mathrm{B}}, \varphi_{\mathrm{B}}\right)$ параметрів та різниці температур $\Delta t_{\text {п }}$ між внутрішнім і припливним повітрям.

\section{IV. ВИСНОВКИ}

Використана створена авторами інноваційна математична дослідницька модель впровадженої центральної прямотечійної системи кондиціювання повітря операційних чистих кімнат, що дала можливість комп'ютерного оцінювання ऑiі енергоефективності на основі ексергетичного ККД $\eta_{\mathrm{e}}$ залежно від різних факторів, що впливають на ііі роботу, зокрема параметрів зовнішнього $\left(t_{3}, d_{3}\right)$ [20]. Наведено залежність ексергетичного ККД $\eta_{\mathrm{e}}$ впровадженої центральної прямотечійної системи кондиціювання повітря операційних чистих кімнат з рекуперативним повітроохолодником повітропродуктивністю 4300 кг/год від параметрів зовнішнього $\left(t_{3}, d_{3}\right)$ повітря за різних внутрішніх $\left(t_{\mathrm{B}}, \varphi_{\mathrm{B}}\right)$ параметрів та різниці температур $\Delta t_{\Pi}$ між внутрішнім і припливним повітрям, який показав, що максимальні значення ексергетичного ККД цієї СКП досягає за відносно нижчих температур навколишнього середовища.
Показано, що впроваджену СКП для забезпечення мікроклімату в операційних чистих кімнатах ощадніше використовувати за температур зовнішнього повітря $t_{3} \leq 35^{\circ} \mathrm{C}$, та 3 якомога вищою різницею температур між внутрішнім i припливним повітрям $\Delta t_{\text {п }} \geq 6,0^{\circ} \mathrm{C}$, що дасть можливість отримати високий ексергетичний ККД $\eta_{\mathrm{e}} \geq 1,93$, а значить отримати економічно вигідний варіант використання впровадженої системи кондиціювання повітря. Варто відзначити, що вплив вологовмісту $d_{3}$ зовнішнього повітря на значення ексергетичного ККД цієї СКП відсутній.

\section{ЛIТЕРАТУРА}

1. Федотов А.Е. Чистые помещения. Второе изд., перераб. и доп. - М.: АСИНКОМ, 2003. - 576 с.

2. Хаякава И. Чистые помещения. Пер. с японск. М.: Мир, 1990. - 456 с.

3. Уайт В. Технология чистых помещений. Основы проектирования, испытаний и эксплуатации. - М.: Клинрум, 2002. - 304 с.

4. Уайт В. Проектирование чистых помещений. Пер. с англ. - М.: Клинрум, 2004. - 360 с.

5. ГОСТ ИСО 14644-1. Чистые помещения и связанные с ними контролируемые среды. Часть 1. Классификация чистоты воздуха.

6. Соколов Е.Я. Энергетические основы трансформации тепла и процессов охлаждения: учеб. пособие для вузов.- 2-е изд., перераб. / Е.Я. Соколов, В.М. Бродянский. - М.: Энергоиздат, 1981. - 320 с.

7. Шаргут Я. Эксергия / Я. Шаргут, Р. Петела. - М.: Энергия, 1968. - 280 с.

8. Эксергетические расчеты технических систем: справ. пособие / [В.М. Бродянский, Г.П. Верхивкер, Я.Я. Карчев и др.]; под ред. А.А. Долинского, В.М. Бродянского; Ин-т технической теплофизики АН УССР. - Киев: Наук. думка, 1991. - 360 с.

9. Бродянский В.М. Эксергетический метод термодинамического анализа / В.М. Бродянский. - М.: Энергия, 1973. - 296 с.

10. Бэр Г.Д. Техническая термодинамика / Г.Д. Бэр. М.: Мир, 1977. - 518 с.

11. Богословский В.Н. Кондиционирование воздуха и холодоснабжение: Учебник для вузов / В.Н. Богословский, О.Я. Кокорин, Л.В. Петров. - Стройиздат, 1985. - 367 c.

12. Прохоров В.И. Метод вычисления эксергии потока влажного воздуха / В.И. Прохоров, С.М. Шилклопер // Холодильная техника. - 1981, № 9. - С. 37-41.

13. Шилклопер С.М. Эксергетический анализ систем обеспечения микроклимата и энергоснабжения / С.М. Шилклопер, С.И. Жадин // Строительство и архитектура. Сер. 9. - 1982, вып. 4. - С. 18-27.

14. СНиП 2.04.05-86. Отопление, вентиляция и кондиционирование. - М.: ЦИТП Госстроя СССР, 1987. $64 \mathrm{c}$.

15. Янтовский Е.И. Потоки энергии и эксергии / Е.И. Янтовский. - М.: Наука, 1988. - 144 с.

16. Bes T. Egzergia w procesach ogrzewania, klimatyzacji i suszenia / T. Bes // Energetyka Przemysłowa. - 1962. - 10, № 11. - S. 388-392. 
17. Лабай Володимир. Ексергетична ефективність центральних кондиціонерів / Володимир Лабай, Тарас Іванух // V Konferencja naukowa RzeszowskoLwowsko-Koszycka „Aktualne problemy budownictwa i inżynierii środowiska". Zeszyty naukowe Politechniki Rzeszowskiej «Budownictwo $\mathrm{i}$ inżynieria środowiska». Z. 32, część 2: Inżynieria Środowiska. - Rzeszów: Politechnika Rzeszowska, 25-26 września 2000 r. - S. 229-235.

18. Labay V. Innovation model for energy effective investigations of air conditioning systems for cleanrooms / V. Labay, D. Harasym // ECONTECHMOD - LublinRzeszow: 2014 - Vol. 3, № 1. - P. 47-52.
19. Гарасим Д.І. Оцінювання систем кондиціювання повітря чистих приміщень за діаграмою Грассмана / Гарасим Д.І., Лабай В.Й. // Строительство, материаловедение, машиностроение: Сб. науч. трудов. Вып. № 76. - Дн-вск: ПГАСА, 2014. - С. 95-100.

20. Лабай В.Й. Залежність ексергетичного ККД системи кондиціювання повітря операційних чистих кімнат від коефіцієнта трансформації холодильної машини / В.Й. Лабай, Д.І. Гарасим // Науково-технічний журнал «Холодильна техніка і технологія», т. 51, вип. 3. Одеса: ОНАХТ, 2015. - С. 14-21.

Отримана в редакції 04.10.2016, прийнята до друку 01.11.2016

D. I. Harasym, V. Y. Labay

Lviv Polytechnic National University, 12 St. Bandery str., Lviv, 79013, Ukraine

\section{THE DEPENDENCE OF THE EXERGETIC OUTPUT-INPUT RATIO OF AIR CONDITIONING SYSTEM FOR OPERATING CLEANROOMS ON TEMPERATURE AND MOISTURE CONTENT OF OUTDOOR AIR}

In modern technologies, which are related to energy transformation, namely in air conditioning systems, important places are occupied by equipment and processes, the objective estimation of value of its energy perfection can be defined only on the basis of analysis of its exergy effectiveness.

Innovation mathematical research model, created by the authors, of the implemented central straight flow air conditioning system for operating cleanrooms was used, which gave opportunity to make computer estimation of its energy effectiveness by the virtue of exergetic output-input ratio depending on different factors, which have influence on its work, in particular on parameters of outdoor air $\left(t_{\mathrm{out}}, d_{\mathrm{out}}\right)$.

The dependence of exergetic output-input ratio of implemented central straight flow air conditioning system with recuperative air cooler and air productivity that is $4300 \mathrm{~kg} / \mathrm{hr}$ for operating cleanrooms on parameters of outdoor $\left(t_{\mathrm{out}}, d_{\mathrm{out}}\right)$ air by different indoor parameters $\left(t_{\mathrm{in}}, d_{\mathrm{in}}\right)$ and on temperature difference $\Delta t_{\mathrm{s}}$ between indoor and supplied air was presented. This dependence showed that the exergetic output-input ratio of the system gains its maximum by lower temperatures of outdoor air.

It was shown that for providing the microclimate in operating cleanrooms the implemented central air conditioning system, with the aim of energy saving, should be used by temperature of outdoor air $t_{\mathrm{out}} \leq 35^{\circ} \mathrm{C}$ and by higher (as much as possible) temperature difference between indoor and supplied air $\Delta t_{\mathrm{s}} \geq 6,0^{\circ} \mathrm{C}$. This will give the opportunity to get a high exergetic output-input ratio $\eta_{\mathrm{e}} \geq 1,93$, which means to get the most economical variant of exploitation of the implemented air conditioning system. It is worth to mention that moisture content $d_{\text {out }}$ of outdoor air has no influence on exergetic output-input ratio of this air conditioning system.

Keywords: Exergetic balance; Air conditioning systems; Cleanrooms; Exergetic efficiency; Temperature and moisture content of outdoor air

\section{REFERENCES}

1. Fedotov A.E. 2003. Chistye pomeshcheniia. Vtoroe izd., pererab. i dop. - Moskva: ASINKOM, 2003. - 576 (in Russian).

2. Hayakava I. 1990. Chistye pomeshcheniia. Per. s iaponsk. - Moskva: Mir. - 456 (in Russian).

3. Whyte W. 2002. Tekhnologiia chistykh pomeshchenii. Osnovy proektirovaniia, ispytanii i ekspluatatsii. - Moskva: Klinrum. - 304 (in Russian).

4. Whyte W. 2004. Proektirovanie chistykh pomeshchenii. Per. s angl. - Moskva: Klinrum. - 360 (in Russian).
5. GOST ISO 14644-1. Chistye pomeshcheniia i sviazannye s nimi kontroliruemye sredy. Chast' 1. Klassifikatsiia chistoty vozdukha (in Russian).

6. Sokolov E.Ia. 1981. Energeticheskie osnovy transformatsii tepla i protsessov okhlazhde-niia: ucheb. posobie dlia vuzov. - 2-e izd., pererab. / E.Ia. Sokolov, V.M. Brodianskii. - Moskva: Energoizdat. - 320 (in Russian).

7. Shargut Ia. 1968. Eksergiia / Ia. Shargut, R. Petela. Moskva: Energiia. - 280 (in Russian).

8. Eksergeticheskie raschety tekhnicheskikh sistem. 1991: sprav. posobie / [V.M. Brodianskii, G.P. Verhivker, Ia.Ia. Karchev i dr.]; pod red. A.A. Dolinskogo, V.M. 
Brodianskogo; In-t tekhnicheskoi teplofiziki AN USSR.Kiev: Nauk. dumka. - 360.

9. Brodianskii V.M. 1973. Eksergeticheskii metod termodinamicheskogo analiza / V.M. Brodianskii. - Moskva: Energiia. - 296 (in Russian).

10.Ber G.D. 1977. Tekhnicheskaia termodinamika / G.D. Ber. - Moskva: Mir. - 518 (in Russian).

11.Bogoslovskii V.N. 1985. Konditsionirovanie vozdukha i kholodosnabzhenie: Uchebnik dlia vuzov / V.N. Bogoslovskii, O.Ia. Kokorin, L.V. Petrov. - Stroiizdat. 367 (in Russian).

12.Prokhorov V.I. 1981. Metod vychisleniia eksergii potoka vlazhnogo vozdukha / V.I. Prokhorov, S.M. Shilkloper // Kholodil'naia tekhnika. - № 9. - 37-41 (in Russian).

13.Shilkloper S.M. 1982. Eksergeticheskii analiz sistem obespecheniia mikroklimata i energosnabzheniia / S.M. Shilkloper, S.I. Zhadin // Stroitel'stvo i arkhitektura. Ser. 9. - Vyp. 4. - 18-27 (in Russian).

14.SNiP 2.04.05-86. 1987. Otoplenie, ventiliatsiia i konditsionirovanie. - Moskva: TsITP Gosstroia SSSR. - 64 (in Russian).

15.Iantovskii E.I. 1988. Potoki energii i eksergii / E.I. Iantovskii. - Moskva: Nauka. - 144 (in Russian).

16.Bes T. 1962. Egzergia w procesach ogrzewania, klimatyzacji i suszenia / T. Bes // Energetyka Przemysłowa. 10, № 11. - 388-392 (in Polish).
17.Labai Volodymyr. 2000. Eksergetychna efektyvnist' tsentral'nykh kondytsioneriv / Volodymyr Labai, Taras Ivanukh // V Konferencja naukowa RzeszowskoLwowsko-Koszycka „Aktualne problemy budownictwa i inżynierii środowiska". Zeszyty naukowe Politechniki Rzeszowskiej «Budownictwo i inżynieria środowiska». Z. 32, część 2: Inżynieria Środowiska. - Rzeszów: Politechnika Rzeszowska, 25-26 września. - 229-235 (in Ukrainian).

18.Labay V. 2014. Innovation model for energy effective investigations of air conditioning systems for cleanrooms / V. Labay, D. Harasym // ECONTECHMOD - LublinRzeszow: 2014 - Vol. 3, № 1. - 47-52 (in English).

19.Garasym D.I. 2014. Otsiniuvannia system kondytsiiuvannia povitria chystykh prymishchen' za diagramoiu Grassmana / Garasym D.I., Labay V.I. // Stroitel'stvo, materialovedenie, mashynovedenie: Sb. nauch. trudov. Vyp. № 76. - Dn-vsk: PGASA. - 95-100 (in Ukrainian).

20.Labai V.I. 2015. Zalezhnist' eksergetychnogo KKD systemy kondytsiiuvannia povitria operatsiinykh chystykh kimnat vid koefitsiienta transformatsii kholodyl'noi mashyny / V.I. Labai, D.I. Garasym // Naukovo-tekhnichnykh zhurnal «kholodyl'na tekhnika i tekhnologiia», t. 51, vyp. 3. - Odesa: ONAKHT. - 14-21 (in Ukrainian).

Received 04 October 2016 Approved 01 November 2016 Available in Internet 30 November 2016 